\title{
Expression and therapeutic relevance of heat-shock protein 90 in pancreatic endocrine tumors
}

\author{
Philipp Mayer*, Andreas Harjung ${ }^{*}$ Marco Breinig, Lars Fischer ${ }^{1}$, \\ Volker Ehemann, Mona Malz, Hans Scherübl', Sarah Britsch, Jens Werner ${ }^{1}$, \\ Michael A Kern, Hendrik Bläker, Peter Schirmacher and Frank Bergmann
}

\author{
Institute of Pathology, University of Heidelberg, Im Neuenheimer Feld 220, D-69120 Heidelberg, Germany \\ ${ }^{1}$ Department of General Surgery, University of Heidelberg, Im Neuenheimer Feld 110, D-69120 Heidelberg, Germany \\ ${ }^{2}$ Medical Clinic - Gastroenterology and Gastrointestinal Oncology, Vivantes Klinikum Am Urban, Dieffenbachstrasse 1, D-10967 \\ Berlin, Germany \\ (Correspondence should be addressed to F Bergmann; Email: frank.bergmann@med.uni-heidelberg.de) \\ *(P Mayer and A Harjung contributed equally to this work)
}

\begin{abstract}
Pancreatic endocrine tumors (PET) represent a heterogenous group of neoplasms. Although surgical resection is considered a safe and effective treatment for many PET, therapeutic options for inoperable and progressive PET are limited. The expression of heat-shock protein (HSP) 90 was investigated in 120 clinically and pathomorphologically well-characterized PET from 84 patients using immunohistochemistry. In addition, in 19 snap-frozen PET and in three healthy pancreatic tissues, we performed immunoblot analyses, and in 15 snap-frozen PET and in three healthy pancreatic tissues, we investigated the expression of HSP90 isoforms by means of semiquantitative RT-PCR. Functional tests were conducted using the human pancreas carcinoid cell line BON and the mouse insulinoma cell line $\beta$-TC-3. HSP90 was expressed in $95 \%$ of the PET patients. The transcript levels of the HSP90 isoforms HSP90 $\alpha$, HSP90 $\beta$, glucose-related protein 94, and TNF receptor-associated protein 1 were significantly increased in PET compared with non-neoplastic pancreatic tissues. The treatment of the cell lines BON and $\beta-T C-3$ with the HSP90 inhibitors 17-allylamino-17-demethoxygeldanamycin and 17-dimethylaminoethylamino17-demethoxy-geldanamycin resulted in significant, dose-dependent reduction of cell viability, cell cycle arrest, and increased apoptosis. Furthermore, HSP90 inhibition induced the degradation and inactivation of several oncogenetic HSP90 client proteins in a time- and dose-dependent manner. HSP90 inhibitors increased the therapeutic effects of doxorubicin and 5-fluorucacil in BON and $\beta$-TC-3 cells. HSP90 is expressed in the vast majority of PET and its inhibition reveals significant treatment effects in vitro. Thus, HSP90 qualifies as a promising new target.
\end{abstract}

Endocrine-Related Cancer (2012) 19 217-232

\section{Introduction}

Pancreatic endocrine tumors (PET), which represent $1-2 \%$ of all pancreatic neoplasms, are biologically and clinically heterogeneous (Heitz et al. 2004). Based on a panel of clinical and morphological characteristics, PET are classified as benign well-differentiated PET, well-differentiated PET of uncertain behavior, welldifferentiated endocrine carcinomas, and poorly differentiated endocrine carcinomas (Heitz et al. 2004). Furthermore, depending on clinical syndromes related to hormone production by the tumors, PET are divided into functioning and nonfunctioning tumors (Heitz et al. 2004).

For the PET, surgical resection of the tumors is considered the therapy of first choice (Plockinger et al. 2004). This may also be applied to PET with hepatic metastasis and has been reported to result in 5-year survival rates for patients with operable malignant PET of up to $77 \%$ (Kazanjian et al. 2006). Nevertheless, treatment options are limited for inoperable and 
progressive malignant PET, which present distant metastases at the time of diagnosis in up to $87 \%$ of cases (Kirshbom et al. 1999). Thus, current chemotherapeutic concepts for inoperable or progressive malignant PET with streptozotocin in combination with 5-fluoruracil (5-FU) or doxorubicin as first-line treatment lead to a significant tumor response in only 20-35\% of the patients (Eriksson et al. 2009).

This urges the need for innovative nonsurgical treatment options for PET. In a variety of other neoplasms, including pancreatic ductal adenocarcinoma (Song et al. 2008), hepatocellular carcinoma (Breinig et al. 2009), breast cancer (Baselga 2010), non-small-cell lung cancer (Shimamura \& Shapiro 2008), esophageal and gastric cancers (Lee et al. 2009), multiple myeloma (Richardson et al. 2010), acute myeloid leukemia (Lancet et al. 2010), and prostate cancer (Altieri 2010, Suzuki et al. 2010), heatshock protein (HSP) 90 has been considered a promising new therapeutic target. HSP90 is a molecular chaperone that comprises $1-2 \%$ of total cellular protein content and regulates the correct folding, activity, function, and stability of over 200 client proteins (Trepel et al. 2010). The most important HSP90 isoforms are the highly inducible HSP90 $\alpha$ (HSP90AA) and the constitutively expressed HSP90 $\beta$ (HSP90AB), both of which are mostly found in the cytoplasm and constitute the HSP90A family (Csermely et al. 1998, Sreedhar et al. 2004, Chen et al. 2005). Higher eukaryotes possess their own endoplasmatic reticulum (ER) isoform, glucose-related protein 94 (GRP94; Ni \& Lee 2007), which constitutes the HSP90B family and is important for maintaining the ER-homeostasis (Pan et al. 2009), as well as their own mitochondrial isoform TNF receptor-associated protein 1 (TRAP1; Csermely et al. 1998), which is part of a mitochondrial pathway maintaining mitochondrial integrity (Kang et al. 2007).

Many client proteins of HSP90 are involved in signal transduction pathways whose dysregulation may drive cancer (Workman et al. 2007, Pearl et al. 2008, Trepel et al. 2010). In this context, the effects of HSP90 on several oncoproteins, e.g. B-RAF, may be enhanced by the presence of mutations, as in contrast to the wild-type proteins, the mutated forms of these oncoproteins are preferentially folded and protected by HSP90 (Grbovic et al. 2006, Pick et al. 2007). Furthermore, cancer cells depend on chaperones in general to manage cellular stress like hypoxia, acidosis, and nutrient deprivation, induced by the tumor environment, and stress associated with the activation of oncogenes (Workman 2004, Pearl et al. 2008).
Recently, HSP90 inhibitors have been considerably improved (Workman et al. 2007). 17-Allylamino17-demethoxygeldanamycin (17-AAG) and 17-dimethylaminoethylamino-17-demethoxygeldanamycin (17-DMAG), two of 14 HSP90 inhibitors currently undergoing clinical trials, are based on the natural product geldanamycin (Porter et al. 2010) and have shown relevant antitumor activity in preclinical studies (Hollingshead et al. 2005, Usmani et al. 2009, Trepel et al. 2010). Clinical trials have been initiated for both (Trepel et al. 2010), and phase III clinical trials involving 17-AAG are currently under way (Usmani et al. 2009).

The aim of this study was to investigate the expression and putative role of HSP90 as a therapeutic target in PET.

\section{Materials and methods}

\section{Patients}

One hundred and twenty-two PET from 86 patients, who had undergone resections for PET between 1991 and 2009, were included in the study (Supplementary Table 1, see section on supplementary data given at the end of this article). In 120 cases, formalin-fixed, paraffin-embedded tumor tissues were obtained. For histological evaluation, sections were stained with hematoxylin and eosin. The diagnosis was established according to the criteria recommended by the World Health Organization (2004). Freshly frozen tissue samples were available from 21 patients. Clinical data were obtained from the prospective database of the Department of General Surgery at the University of Heidelberg. The study was approved by the ethics committee of the University of Heidelberg.

The 86 patients ( 41 women and 45 men) included in our study had an average age of 53.7 years (range from 13 to 85 years) at the time of diagnosis. Clinically, a functional syndrome was reported in 30 cases (22 insulinomas, seven gastrinomas, and one glucagonoma). Seven patients were known to be affected by the multiple endocrine neoplasia type 1 syndrome.

The 122 tumors comprised 77 primary PET, four intrapancreatic recurrences (three pancreatic head and one tail), 26 lymph node metastases (corresponding primary obtained in 23 of these cases), 12 liver metastases (corresponding primary in ten cases), and three distant metastases other than liver (corresponding primary in two cases). Of the 77 primary PET, 33 were localized in the pancreatic head, 27 in the tail, 13 in the body, and four affected the body and tail. The average size of the primaries was $3.7 \mathrm{~cm}$ (range from 0.7 to 
$10 \mathrm{~cm}$ ) in largest diameter. The number of mitotic figures in 10 high-power fields ranged from 0 to 100 (average 6.5). Correspondingly, the Ki-67 proliferation index ranged from 0 to $95 \%$ (average $8 \%$ ). By means of immunohistochemistry, the tumors of 24 patients revealed positivity for insulin (28\%), whereas an expression of gastrin was found in the tumors of 23 patients $(27 \%)$. An expression of serotonin and glucagon was seen in tumors of nine patients each $(10 \%)$. The tumors of four patients $(5 \%)$ expressed somatostatin. Overlapping positivity for more than one hormone was observed in 17 cases. On the basis of the tumor size, the presence or absence of metastases, gross invasion, perineural invasion, and angioinvasion, as well as the mitotic activity of the tumors (mitotic count, Ki-67 proliferative activity), the diagnosis of a benign well-differentiated PET was made in 13 patients, well-differentiated PET with uncertain behavior in 16 patients, well-differentiated endocrine carcinoma in 51 patients, and poorly differentiated endocrine carcinoma in six patients.

Follow-up information could be obtained for 67 patients. After follow-up periods between 2 and 177 months (average 48.1 months), 40 patients $(60 \%)$ showed no evidence of disease. Eight patients (12\%) were alive with recurrent disease (local recurrence and/or distant metastases) between 26 and 164 months after surgery (average 62.4 months). Eighteen patients $(27 \%)$ died from disease after follow-up periods between 1 and 196 months (average 29.9 months). One patient died 1 month after tumor enucleation of an unrelated cause. Local or systemic recurrences were not observed in patients with benign well-differentiated PET (average follow-up period 39.3 months).

\section{Immunohistochemical analysis}

To evaluate the HSP90 expression in PET and nonneoplastic pancreatic tissues, the immunohistochemical analyses were performed based on tissue microarrays using the avidin-biotin complex method with anti-HSP90 (1:70; Millipore, Billerica, MA, USA) as primary antibody, as described previously (Bergmann et al. 2009). Antigen retrieval was performed by heat pretreatment in a citrate buffer (pH 6.1) for $30 \mathrm{~min}$. To confirm the tissue microarraybased results, in 15 selected cases, the stainings were repeated using regular whole tissue specimen. The latter displayed homogeneous staining patterns of HSP90 in all cases. For quantitative analyses of expression of $H S P 90$, the respective immunohistochemical staining intensities were scored as negative (score: 0), weakly positive (score: 1), moderately positive (score: 2), or strongly positive (score: 3 ) by three observers blinded to the diagnosis (F B, P M, and A H), as previously reported (Bergmann et al. 2009). The hormone expression was determined as described previously (Bergmann et al. 2009).

\section{Cell culture}

For functional analyses, the murine insulinoma cell line $\beta$-TC-3 (obtained from the German Collection of Microorganisms and Cell Cultures, Braunschweig, Germany) and the human carcinoid cell line BON were used and cultured, as described previously (Bergmann et al. 2009).

\section{Reagents}

The HSP90 inhibitors 17-AAG and 17-DMAG (both from LC Laboratories, Woburn, MA, USA) were solubilized in dimethyl sulfoxide before use. For chemotherapeutics, 5-FU (Fluorouracil GRY; Teva, Aesch, Switzerland) and doxorubicin (Doxo Cell, Cell Pharm, Hannover, Germany) were obtained.

\section{Cell viability measurement}

A total of 4000 cells per well ( $\beta$-TC-3) or 5000 cells per well (BON) were seeded onto 96-well plates and allowed to attach overnight. After $24 \mathrm{~h}$, the medium was replaced by 17-AAG, 17-DMAG, doxorubicin, and/or 5-FU in the concentrations indicated below. After the incubation time of 24 or $48 \mathrm{~h}, 25 \mu 1$ 3-(4,5dimethylthiazol-2-yl)-2,5-diphenyltetrazolium bromide (MTT) stock solution (prepared as described by Rexen \& Emborg (1992)) was added to each well and the plates were incubated for $2 \mathrm{~h}$. Then, the formazan produced by the cells was dissolved by adding $150 \mu \mathrm{l}$ lysis buffer (prepared by dissolving SDS (Serva, Heidelberg, Germany) in a 1:1 mixture of water and $N, N$-dimethylformamide (VWR International, Fontenay-sous-Bois, France) to a concentration of $20 \%$ (w/ $\mathrm{v}) ; \mathrm{pH}$ in the lysing buffer was adjusted to $\sim 2$ by adding $32 \% \mathrm{HCl}$ ). The solubilized formazan product was spectrophotometrically quantified using a microplate spectrophotometer (Multiskan MS 6.0; Labsystems, Helsinki, Finland) at a wavelength of $490 \mathrm{~nm}$ with a reference at a wavelength of $690 \mathrm{~nm}$. Assays were performed six times, and data were expressed as the mean \pm s.D. $(n=6)$.

\section{Cell cycle analysis and detection of apoptosis}

Analyses for cell cycle were performed using a PAS II flow cytometer (Partec, Münster, Germany) equipped with a mercury vapor lamp $(100 \mathrm{~W})$ and a filter 
Table 1 Primers used to analyze the expression levels of the HSP90 mRNAs coding for the respective HSP90 isoforms

\begin{tabular}{|c|c|c|}
\hline Gene & $\begin{array}{l}\text { Direction } \\
\text { of primer }\end{array}$ & Sequence $\left(5^{\prime} \rightarrow 3^{\prime}\right)$ \\
\hline \multirow[t]{2}{*}{ HSP90AA1.1 } & Forward & GGGGTACCCTACGGGGAGCG \\
\hline & Reverse & AGAGCGGAGGAAGAGCGCCA \\
\hline \multirow[t]{2}{*}{ HSP90AA1.2 } & Forward & TATAAGGCAGGCGCGGGGGT \\
\hline & Reverse & АССТССТССТССТССАTCGGT \\
\hline \multirow[t]{2}{*}{ HSP90AB1 } & Forward & CGAGGGCGATGAGGATGCGT \\
\hline & Reverse & GGGGAGCCAGGTGGGACAGG \\
\hline \multirow[t]{2}{*}{ HSP90B1 } & Forward & GCGGCTGGAGGTGTGAGGAT \\
\hline & Reverse & CCCGAAGGTCAGCAGGACGC \\
\hline \multirow[t]{2}{*}{ TRAP1 } & Forward & TGGGCTCCAGCGTTGCACTG \\
\hline & Reverse & AGCAGCTCCCGGCTGAGGTT \\
\hline \multirow[t]{2}{*}{$18 S$} & Forward & AAACGGCTACCACATCCAAG \\
\hline & Reverse & ССTCCAATGGATCCTCGTTA \\
\hline
\end{tabular}

combination for 2,4-diamidino-2-phenylindole (DAPI)-stained single cells. Cells were harvested with trypsin/EDTA, treated with $2.1 \%$ citric acid $/ 0.5 \%$ Tween 20 , and stained with a phosphate buffer $\left(7.2 \mathrm{~g} \mathrm{Na}_{2} \mathrm{HPO}_{4} \times 2 \mathrm{H}_{2} \mathrm{O}\right.$ in $100 \mathrm{ml}$ distilled $\left.\mathrm{H}_{2} \mathrm{O}\right) \mathrm{pH} 8.0$ containing DAPI, as described previously (Ehemann et al. 1999). Analyses for apoptosis and DNA fragmentation were performed using a FACScalibur flow cytometer (Becton Dickinson, Franklin Lakes, NT, USA) equipped with a $488 \mathrm{~nm}$ air-cooled argon laser with filter combinations for propidium iodide. To detect apoptotic cells, cells were prepared according to Nicoletti stain with modifications (Ehemann et al. 1999, 2003) and measurements were acquire in Fl-2 in logarithmic mode and calculated by setting gate over the first three decades. DNA fragmentation was detected with a terminal deoxynucleotidyl transferase dUTP nick end labeling (TUNEL) kit (Roche), as described previously (Ehemann et al. 2003). Multiparameter analyses (cell cycle vs TUNEL) were performed on a Galaxy Pro flow cytometer (Partec).

Cells $\left(5 \times 10^{5}\right)$ were seeded onto $10 \mathrm{~cm}$ plates and allowed to attach for $24 \mathrm{~h}$. Then, the medium was changed, $1 \mu \mathrm{M}$ 17-AAG or 17-DMAG was added to $\beta$ TC-3 and $0.05 \mu \mathrm{M}$ 17-AAG or 17-DMAG was added to BON. After an additional incubation time $(24,48$, and $72 \mathrm{~h}$ ), cell cycle analyses and Nicoletti staining were performed. TUNEL staining was performed after an incubation time of $48 \mathrm{~h}$. Assays were performed in triplicate. Data are the mean $(n=3)$.

\section{Western immunoblot analysis}

Western immunoblot analyses were performed with protein lysates obtained from the cell lines BON and $\beta-\mathrm{TC}-3$ as well as from snap-frozen tissue samples, comprising four benign well-differentiated endocrine tumors, three well-differentiated endocrine tumors of uncertain behavior, ten well-differentiated endocrine carcinomas, two poorly differentiated endocrine carcinomas, and three non-neoplastic pancreatic tissues. The three snap-frozen non-neoplastic pancreatic tissue samples consisted lobules of predominantly exocrine cells, containing scattered islets. For protein isolation from cell lines, the cell monolayers were washed with PBS (PAA Laboratories, Cölbe, Germany) and lysed $(10 \%$ Chaps $(10 \times), 0.2 \%$ DTT $(200 \times)$, and $2 \%$ protease inhibitor cocktail (Sigma)). The protein concentrations were quantified by Nanodrop ND1000 Spectrophotometer (Nanodrop Technologies,
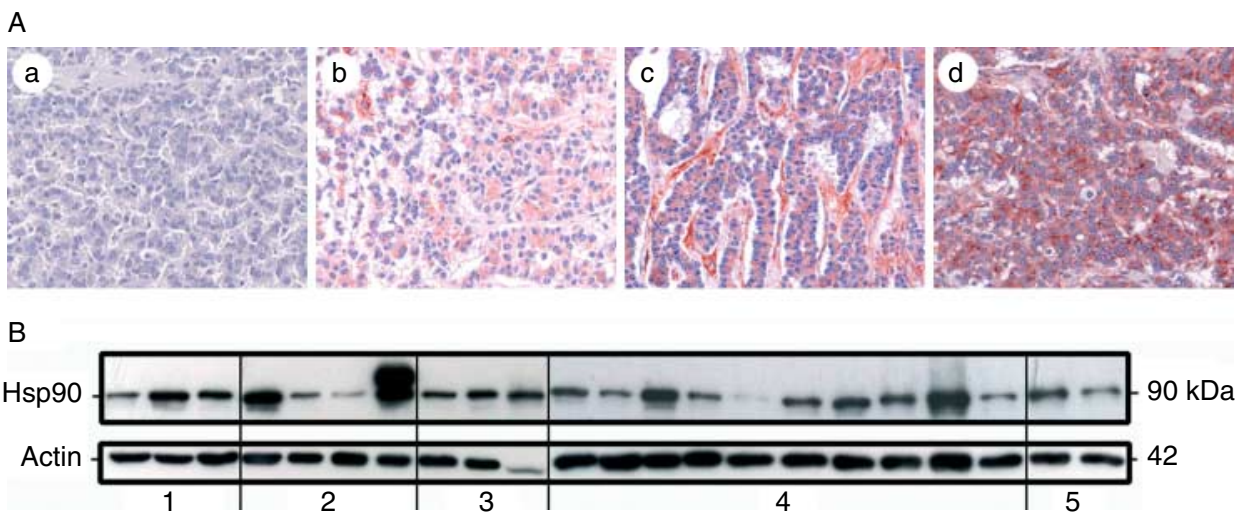

Figure 1 HSP90 is expressed in PET. (A) Immunohistochemical reactivity for HSP90 in various PET. (a) No tumor staining, score: 0; (b) weak tumor staining, score: 1; (c) moderate tumor staining, score: 2; (d) strong tumor staining, score: 3. Original magnification: $\times 64$. (B) HSP90 western immunoblot analysis revealed that HSP90 is expressed in all freshly frozen tissue samples. 1, nonneoplastic pancreatic tissues; 2, benign well-differentiated PET; 3, well-differentiated PET of uncertain behavior; 4, welldifferentiated endocrine carcinoma; 5 , poorly differentiated endocrine carcinoma. Actin served as a loading control. 
Wilmington, DE, USA). Thirty micrograms of the respective protein were separated by SDS-PAGE (using 8-10\% gels), transferred onto nitrocellulose membrane (Whatman, Dassel, Germany), probed with different antibodies (listed below), and detected by the Amersham ECL-detection system (GE Healthcare, Buckinghamshire, UK) and FUJI SuperRX medical X-ray films (Fujifilm, Düsseldorf, Germany). The following antibodies were used: HSP70 (1:6.000; Santa Cruz Biotechnologies, Santa Cruz, CA, USA), HSP90 (1:1.000; Assay Designs, Ann Arbor, MI, USA), MET (1:200; Santa Cruz Biotechnologies), phospho-p44/42 MAPK (pErk1/2, 1:500; Cell Signaling, Beverly, MA, USA), p44/42 MAPK (extracellular signal-regulated kinase 1/2 (Erk1/2), 1:1.000; Cell
Signaling), Phospho-Akt (Ser473, 1:500; Cell Signaling), Akt (1:1.000; Cell Signaling), poly(ADP-ribose) polymerase (PARP; 1:500; Cell Signaling), Raf1 (1:200; Santa Cruz Biotechnologies), IGF-IR $\beta$ (C-20) (1:200; Santa Cruz Biotechnologies), CDK4 (1:500; Invitrogen), and actin (1:10.000; MP Biomedicals, Munich, Germany). All western immunoblot analyses were performed three times.

\section{Real-time PCR}

RT-PCR analyses were performed with total RNA isolated from three span-frozen benign welldifferentiated endocrine tumors, four well-differentiated endocrine tumors of uncertain behavior, eight well-
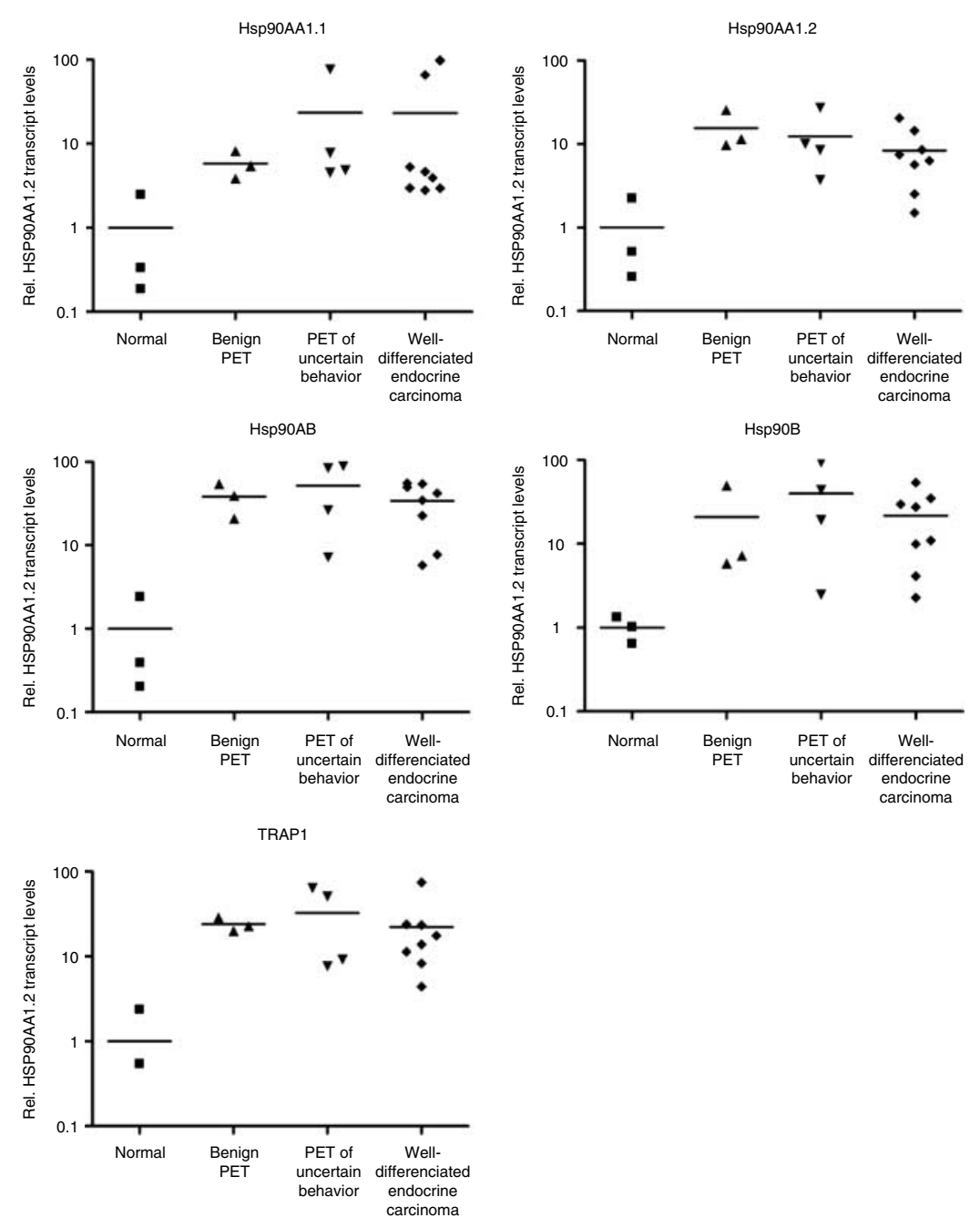

Figure 2 Transcript levels of HSP90 isoforms are elevated in PET compared with non-neoplastic pancreatic tissue. By means of semiquantitative RT-PCR, all HSP90 mRNAs were significantly overexpressed in the freshly frozen PET samples compared with non-neoplastic pancreatic tissues $(P<0.005)$. HSP90AA1.1 and HSP90AA1.2 code for HSP90 $\alpha$, HSP90AB codes for HSP90 $\beta$, HSP90B codes for Grp94, and TRAP1 codes for the identically named protein. 
differentiated endocrine carcinomas, and three nonneoplastic pancreatic tissues. The three snap-frozen non-neoplastic pancreatic tissue samples consisted of lobules of predominantly exocrine cells, containing scattered islets. For isolation and purification of total RNA, the NucleoSpin RNA II kit (Macherey-Nagel, Düren, Germany) was used according to the manufacturer's protocol. For the semiquantitative real-time PCR, the TaqMan-PCR Technology (Prism 7300; Applied Biosystems, Darmstadt, Germany) was used. The following cycling program was applied using the SYBR Green (Absolute SYBR Green ROX Mix, Epsom, UK): $95^{\circ} \mathrm{C}$ for $10 \mathrm{~min}$, followed by 40 cycles of $95{ }^{\circ} \mathrm{C}$ for $15 \mathrm{~s}$, and $60{ }^{\circ} \mathrm{C}$ for $60 \mathrm{~s}$ (Prism 7300; Applied Biosystems). The primers are listed in Table 1. The amount of each mRNA coding for the respective HSP90 isoforms was detected by RT-PCR. For each experimental sample, the relative value obtained was normalized using the value derived from the housekeeping gene $18 S$ in the corresponding PCR. For specific normalization, the standard curve method was used. Assays were performed in triplicate.

\section{Statistical analyses}

Statistical analyses were performed using the Student's $t$-test, the Wilcoxon rank-sum, or the log-rank test. All statistical analyses were two sided. For the MTT assays and the RT-PCR results, the Wilcoxon rank-sum test was used. Differences between treated and untreated cells in the percentages of cells in the distinct phases of cell cycle and in the percentages of cells in sub G1 phase were analyzed using the Student's $t$-test. The Kaplan-Meier survival curves were compared using the log-rank test. All statistical analyses took the number of samples into account. The asterisks in each graph indicate statistically significant changes given as $P$ values: $* P<0.05, * * P<0.01 . P$ values $<0.05$ were considered statistically significant.

\section{Results}

\section{HSP90 is expressed in almost all PET}

In the immunohistochemical analyses, HSP90 was expressed in PET from 80 patients (Fig. 1A). The HSP90 expression displayed a diffuse pattern. The expression of $H S P 90$ did not significantly correlate with malignant potential, functional activity, tumor size, mitotic index, Ki-67 positivity, or the immunohistochemical expression of insulin, gastrin, glucagon, or serotonin. Among the primary tumors, patients' overall survival was not dependent on the immunohistochemical expression of HSP9O $(P>0.7408)$. In ten non-neoplastic pancreatic tissues, immunohistochemistry revealed weak to moderate $H S P 90$ expression in islets and ducts and faint to weak expression in acinar cells.

The results of the immunohistochemical analyses were confirmed by western immunoblot analyses, with all 19 examined tumors expressing HSP90 (Fig. 1B).

\section{Transcript levels of HSP90 isoforms are higher in PET than in non-neoplastic pancreatic tissue}

The comparison of the HSP9O mRNA expression in non-neoplastic pancreatic tissues with the expression in PET (irrespectively of the diagnosis) revealed a significant overexpression of all HSP90 mRNAs in PET $(P<0.005$, Fig. 2). For further statistical analysis, the samples were pooled according to their diagnosis. All HSP9O mRNAs were significantly overexpressed in well-differentiated endocrine carcinomas compared with non-neoplastic pancreatic tissues $(P<0.025)$. The overexpression of the HSP90 mRNAs in benign well-differentiated PET and in well-differentiated PET of uncertain behavior compared with nonneoplastic pancreatic tissues was not significant $(P \leq 0.100$ and $P<0.058)$.

\section{7-AAG and 17-DMAG reduce cell viability in PET cell lines}

As shown in Fig. 3, both the human PET cell line BON and the murine PET cell line $\beta$-TC-3 expressed HSP90. As shown in Fig. 4, 17-AAG as well as 17-DMAG significantly reduced cell viability in both the cell lines in a time- and dose-dependent manner $(P<0.010)$. In $\mathrm{BON}$, the half maximal growth inhibitory concentration after $48 \mathrm{~h}$ (IC50) was between 10 and $50 \mathrm{nM}$, in $\beta$-TC-3, $1 \mu \mathrm{M}$.

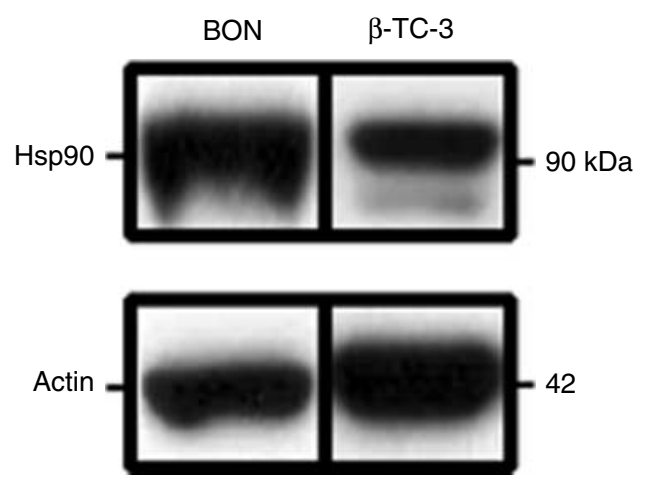

Figure 3 HSP90 is expressed in the PET cell lines BON and $\beta$-TC-3. The expression of HSP90 was detected in BON and $\beta$-TC-3 by western immunoblot analysis. Both cell lines expressed HSP90. Actin served as a loading control. 
A
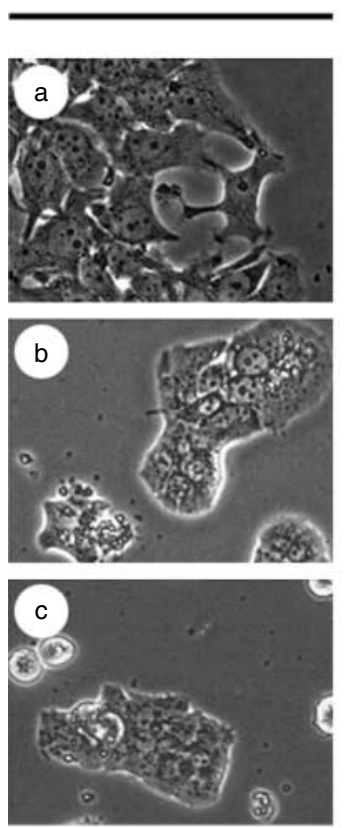

C
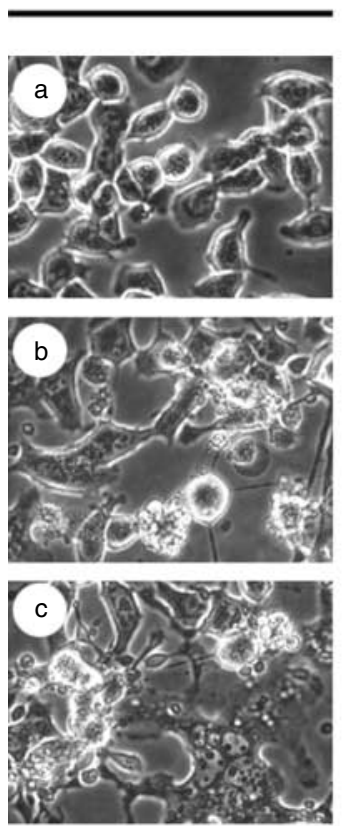

B
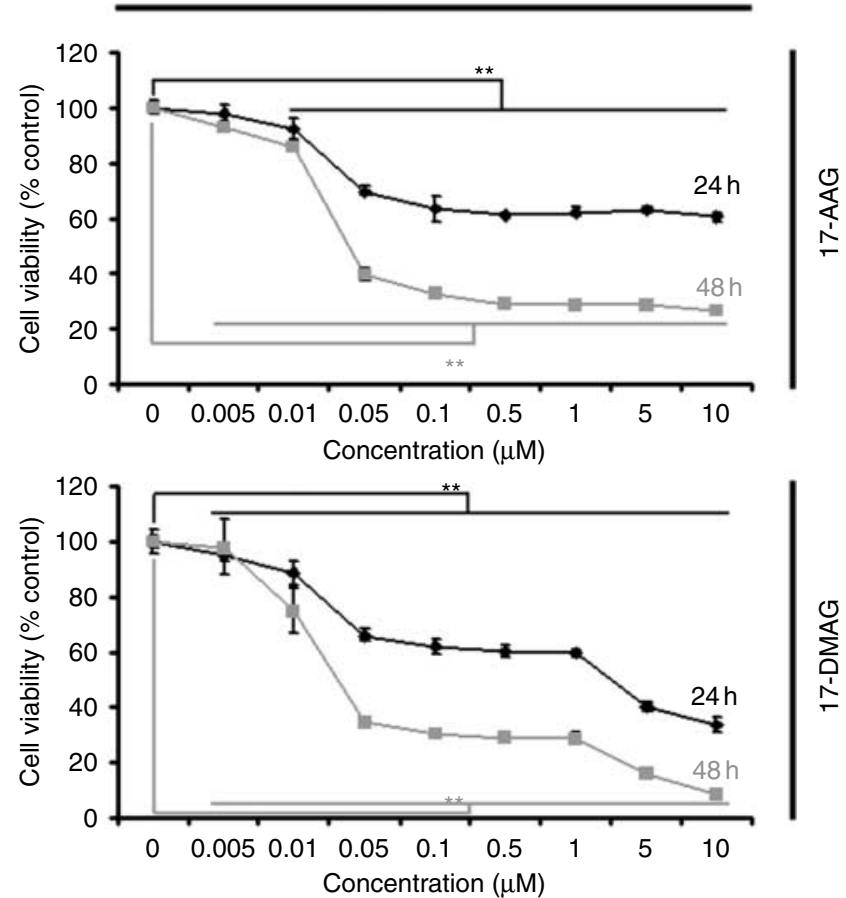

D

$\beta-\mathrm{TC}-3$
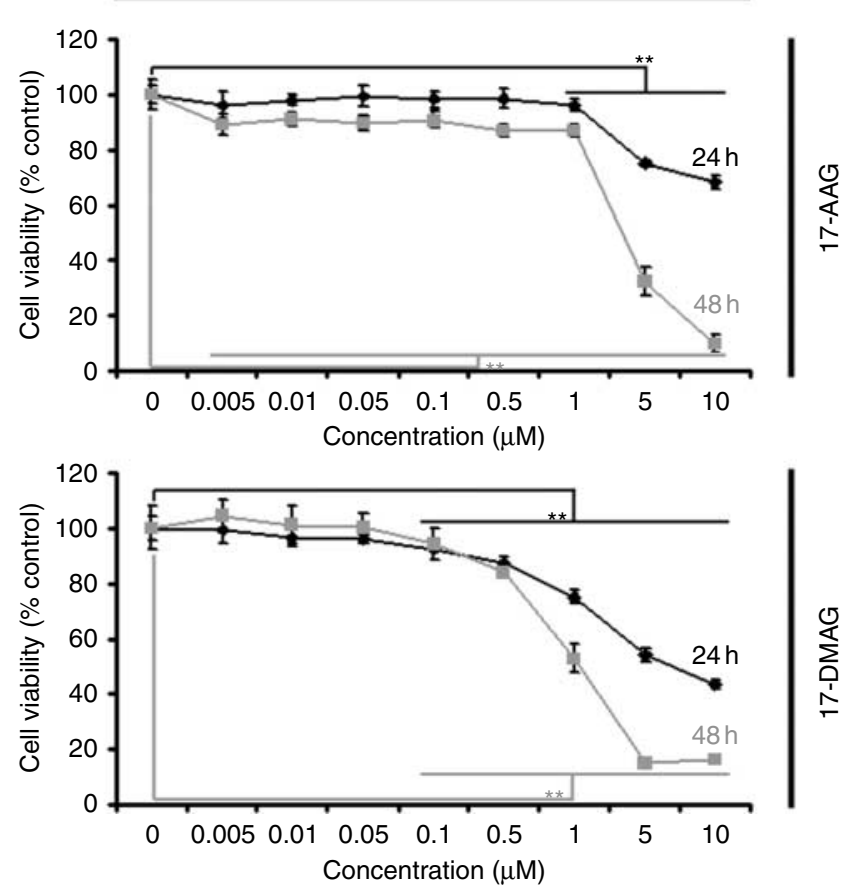

Figure 4 HSP90 inhibition reduces cell viability in PET cells. (A) Human PET cell line BON. (a) Untreated, spindle-shaped to polygonal adherent cells. (b and c) After treatment with $1 \mu \mathrm{M} 17-\mathrm{AAG}$ or 17-DMAG for $24 \mathrm{~h}$, the number of cells is reduced, with some cells showing apoptotic bodies (original magnification: $\times 200$ ). (C) Murine PET cell line $\beta-T C-3$. (a) Untreated, spindle-shaped to polygonal adherent cells growing in multilayers. (b and c) After treatment with $1 \mu \mathrm{M} 17-\mathrm{AAG}$ or 17 -DMAG for $24 \mathrm{~h}$, some cells show apoptotic bodies (original magnification: $\times 200$ ). (B and D) Cell viability was analyzed after 24 and $48 \mathrm{~h}$ with MTT assays. HSP90 inhibition significantly decreased cell viability of BON and $\beta$-TC-3 in a dose- and time-dependent manner $(P<0.010)$. ${ }^{\star \star} P<0.01$. 


\section{HSP90 inhibition induces apoptosis and cell cycle arrest in PET cell lines}

In both BON and $\beta-T C-3$, a significant decrease in the percentage of cells in the S-phase was observed after inhibition with 17-AAG or 17-DMAG on the basis of G1 and G2/M arrest $(P<0.003$, Fig. 5). Moreover, apoptosis significantly increased after inhibition of HSP90, for both inhibitors in both the cell lines (Fig. 6). In BON, inhibition of HSP90 leads to a significantly increased percentage of Nicoletti-positive cells after 48 and $72 \mathrm{~h}(P<0.010)$ and a significantly increased percentage of TUNEL-positive cells after $48 \mathrm{~h}(P<0.016)$ for both $17-\mathrm{AAG}$ and $17-\mathrm{DMAG}$. In $\beta$-TC-3, a significant increase in the percentage of Nicoletti-positive cells was observed after inhibition with 17-AAG or 17-DMAG after 24,48 , and $72 \mathrm{~h}$ $(P<0.022)$ whereas inhibition with $17-\mathrm{AAG}$ or $17-D M A G$ resulted in a significant increase in TUNEL-positive cells after $48 \mathrm{~h}(P<0.035)$.

Confirming these results, in both the cell lines, nuclear PARP cleavage was increased after the administration of 17-AAG and 17-DMAG in a timedependent manner (Fig. 7).

\section{HSP90 inhibition induces the depletion and inactivation of several oncogenic client proteins and increases the expression of HSP70 and HSP9O itself}

In both the cell lines, HSP90 inhibition reduced the expression of several HSP90 client proteins in a timeand dose-dependent manner (Fig. 8). This could be demonstrated for v-raf1 murine leukemia viral oncogene homolog 1 (RAF1), CDK4, and protein kinase B (AKT). In BON, HSP90 inhibition also reduced the expression of Met receptor (MET) in a time- and dosedependent manner and of insulin-like growth factor receptor 1 (IGF1R) in a dose-dependent manner. Furthermore, in both the cell lines, the administration of 17-AAG or 17-DMAG inhibited the activation of AKT in a time- and dose-dependent manner and of Erk1/2 in a time-dependent manner, except for Erk1/2 in BON $48 \mathrm{~h}$ after treatment with $5 \mu \mathrm{M}$ 17-DMAG. However, HSP90 inhibition did not alter the expression of ERK1/2, which is not a client of HSP90. HSP90 inhibition also increased the expression of HSP7O and HSP90 itself.

\section{HSP90 inhibition maximizes the effects of the established chemotherapeutic agents doxorubi- cin and 5-FU in vitro}

As shown by MTT assays (Fig. 9), the combined application of one HSP90 inhibitor, 17-AAG or 17-DMAG, together with an established chemotherapeutic agent, doxorubicin or 5-FU, resulted in a further decreased cell viability of BON and $\beta$-TC-3. In both the cell lines, reduction of cell viability after combined applications of doxorubicin with either 17-AAG or 17-DMAG was significantly stronger than the application of the latter agents alone $(P<0.050)$, except for the combination of $0.01 \mu \mathrm{M}$ doxorubicin plus $0.05 \mu \mathrm{M}$ 17-DMAG in BON after $24 \mathrm{~h}$ compared with $0.05 \mu \mathrm{M}$ 17-DMAG alone. The following combinations of 5-FU plus either 17-AAG or 17-DMAG reduced cell
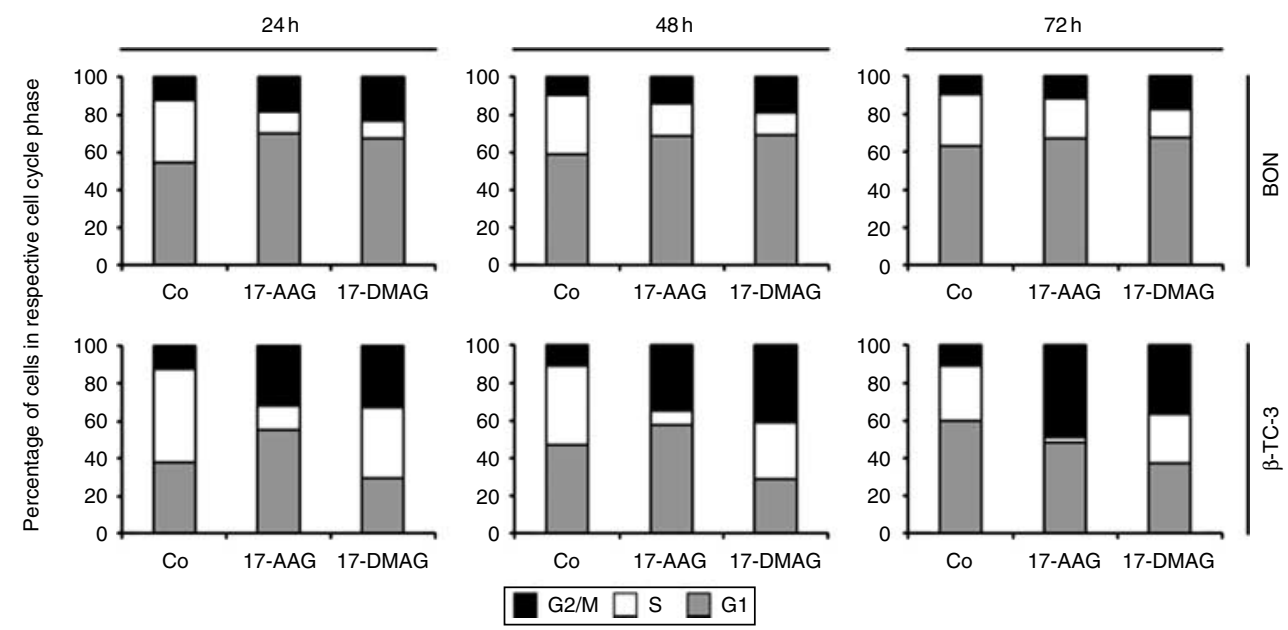

Figure 5 HSP90 inhibition induces cell cycle arrest in PET cells. BON cells were treated with $0.05 \mu \mathrm{M}$ HSP90 inhibitors and $\beta$-TC-3 cells with $1 \mu \mathrm{M}$ HSP90 inhibitors and the cell cycle distribution was analyzed after 24,48 , and $72 \mathrm{~h}$ with FACS measurement. HSP90 inhibition manifested a significant decrease in the percentage of BON and $\beta-T C-3$ cells in the S-phase on the basis of G1 and G2/M arrest $(P<0.003)$. 

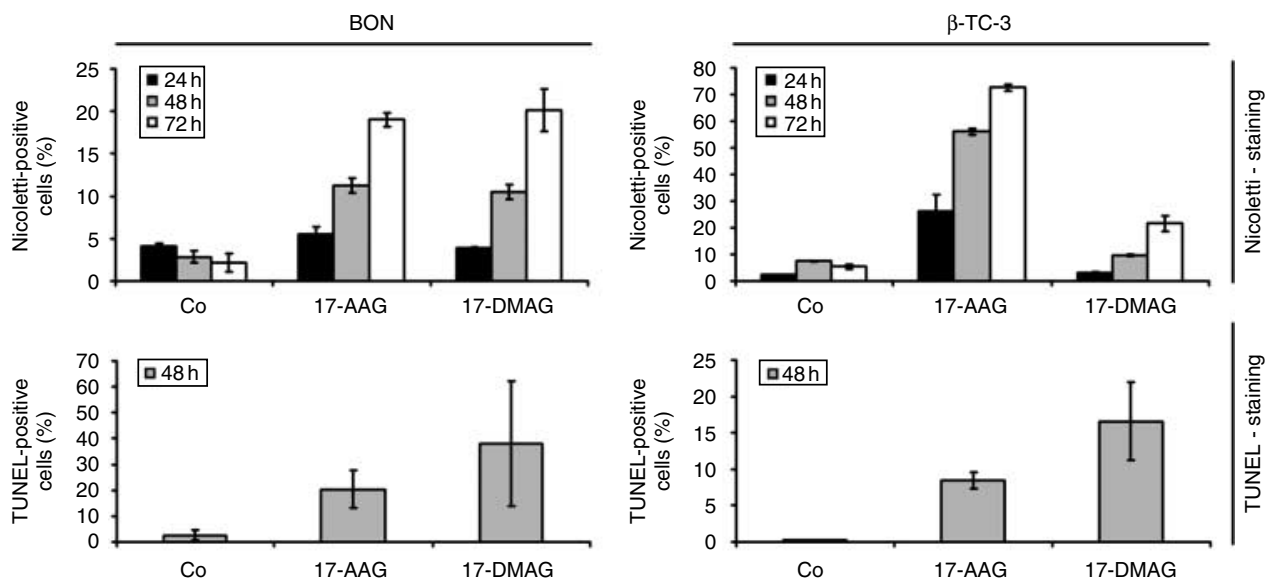

Figure 6 HSP90 inhibition induces apoptosis in PET cells. BON cells were treated with $0.05 \mu \mathrm{M} \mathrm{HSP90} \mathrm{inhibitors,} \beta$-TC-3 cells with $1 \mu \mathrm{M}$ HSP90 inhibitors, and the percentage of Nicoletti-positive and TUNEL-positive cells was analyzed after 24,48 , and $72 \mathrm{~h}$ with FACS measurement. In both BON and $\beta$-TC3, HSP90 inhibition significantly increased the percentage of Nicoletti-positive cells after 48 and $72 \mathrm{~h}(P<0.010)$ and TUNEL-positive cells after $48 \mathrm{~h}(P<0.035)$.

viability significantly stronger than the latter agents alone $(P<0.010)$ : in BON, 5-FU plus 17-AAG after $24 \mathrm{~h}$, and in $\beta$-TC-3, 5-FU plus 17-DMAG after 24 and $48 \mathrm{~h}$ in all concentrations tested.

\section{Discussion}

In this study, we show that HSP90 is expressed in the vast majority of PET, by means of immunohistochemistry and western immunoblot analyses. This was irrespective of clinical and pathological features including the patients' survival, malignant potential, functional activity, tumor size, mitotic index, Ki-67 positivity, or the immunohistochemical expression of insulin, glucagon, gastrin, and serotonin. Furthermore, our RT-PCR analyses indicate that the average transcript levels of all HSP90 isoforms investigated are higher in PET than in non-neoplastic pancreatic tissues. Our findings on PET are in line with the previously reported overexpression of $H S P 90$ in different tumor entities, including colorectal cancer (Zhang et al. 2009), pancreatic ductal adenocarcinoma (Ogata et al. 2000), prostate carcinoma (Elmore et al. 2008), gastrointestinal stromal tumors (Kang et al. 2010), and other mesenchymal tumors (Kang et al. 2010). In colorectal cancer cells, a high expression of HSP90 $\alpha$ has been associated with invasiveness and metastasis (Milicevic et al. 2008). The HSP90 isoform GRP94 was reported to partly account for apoptosis resistance in pancreatic cancer cells (Pan et al. 2009).

The high expression of HSP90 in PET raises the question regarding the biological role of HSP90 in these tumors. Our findings show that in PET, HSP90 safeguards various tumorigenic proteins in vitro,
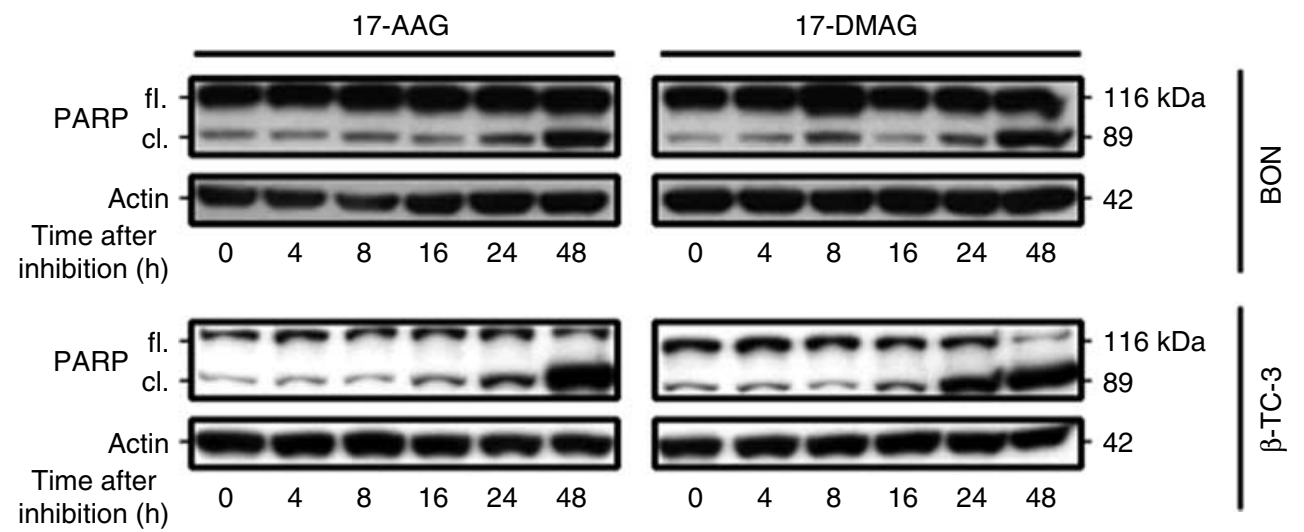

Figure 7 HSP90 inhibition induces PARP cleavage in PET cells. BON cells were treated with $0.05 \mu \mathrm{M}$ HSP90 inhibitors, $\beta$-TC-3 cells with $1 \mu \mathrm{M}$ HSP90 inhibitors, and PARP cleavage was determined semiquantitatively by western immunoblot analysis. In both cell lines, HSP90 inhibition increased PARP cleavage in a time-dependent manner. cl., cleaved; fl., full length. 


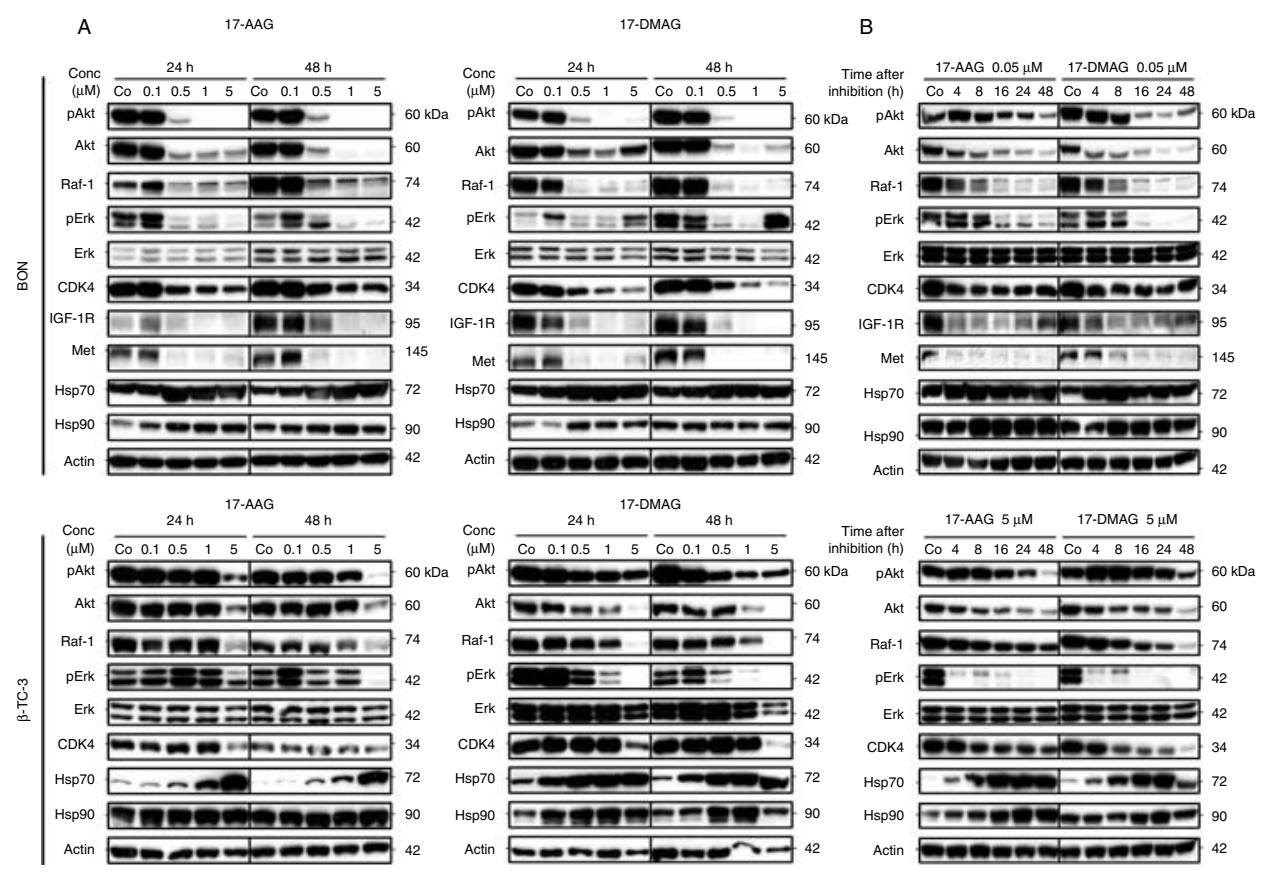

Figure 8 HSP90 inhibition induces the degradation and inactivation of several oncogenic client proteins in a time- and dosedependent manner. The concentration of the proteins was detected semiquantitatively by western immunoblot analyses. $(A) B O N$ and $\beta$-TC-3 cells were treated with increasing concentrations of HSP9O inhibitors, and the expression of the indicated proteins was investigated after 24 and $48 \mathrm{~h}$ with western immunoblotting. HSP90 inhibition induced a concentration-dependent depletion and/or inactivation of the displayed oncogenic client proteins. (B) BON cells were treated with $0.05 \mu \mathrm{M} \mathrm{HSP} 90$ inhibitors, $\beta$-TC-3 with $5 \mu \mathrm{M}$ HSP90 inhibitors, and the expression of the indicated proteins was investigated after different time points with western immunoblotting. HSP90 inhibition induced a time-dependent depletion and/or inactivation of the displayed oncogenic client proteins. Actin served as a loading control. AKT, protein kinase B; CDK4, cyclin-dependent kinase 4; Erk, extracellular signal-regulated kinase; HSP70, heat-shock protein 70; HSP90, heat-shock protein 90; IGF1R, insulin-like growth factor receptor 1; MET, hepatocyte growth factor (HGF) receptor; pAKT, phosphorylated protein kinase B; pErk, phosphorylated extracellular signal-regulated kinase; RAF1, v-raf1 murine leukemia viral oncogene homolog 1.

namely RAF1, AKT, ERK1/2, CDK4, IGF1R, and MET. In the human PET cell line BON and the murine PET cell line $\beta$-TC-3, the HSP90 inhibitors 17-AAG and 17-DMAG lead to a degradation and/or inactivation of these proteins. The latter proteins are part of or associated with important cell signaling pathways, in particular the PI3K/AKT pathway that contributes to cell growth and survival (Hennessy et al. 2005) and the Ras-Raf-MEK-Erk pathway that controls cell proliferation (Mebratu \& Tesfaigzi 2009), and are shown to also affect PET (Guo et al. 2003, Sippel et al. 2003, Tannapfel et al. 2005, Missiaglia et al. 2010). Both pathways can be activated by IGF1R, which is thought to be part of an autocrine feedback loopstimulating proliferation of PET cells (von Wichert et al. 2000), and MET, which seems to support metastasization in PET (Hansel et al. 2004). AKT, as part of the PI3K/AKT pathway, is activated in $\sim 70 \%$ of PET (Guo et al. 2003), and its activation has been associated with a resistance to apoptosis and increased cell proliferation in part by increasing the activity of CDK4 (Hay 2005, Fatrai et al. 2006). ERK1/2, which is part of the Ras-Raf-MEK-Erk pathway, was reported to be activated in PET to a much greater extent than in non-neoplastic $\beta$ cells (Tannapfel et al. 2005). We show that upon HSP90 inhibition in PET cells, these key proteins are degraded or inactivated. Similar findings have been obtained in other tumor cells, e.g. derived from hepatocellular carcinoma (Breinig et al. 2009), breast cancer (Caldas-Lopes et al. 2009), monocytic leukemia (Peng et al. 2010), and esophageal cancer (Wu et al. 2009). Thus, HSP90 is likely to protect the function of these oncogenic factors in PET and thereby acts in a protumorigenic manner.

The aim of our study was to investigate the putative role of HSP90 as an innovative target for the therapy of PET. For inoperable and progressive malignant PET, treatment options are limited. Streptozotocin plus 5-FU or doxorubicin as first-line regime for systemic chemotherapy leads to a significant tumor response in only $20-35 \%$ of cases (Plockinger et al. 2004). Further medical treatment options include somatostatin ana$\operatorname{logs}$ and interferon- $\alpha$ that were shown to result in the 
A
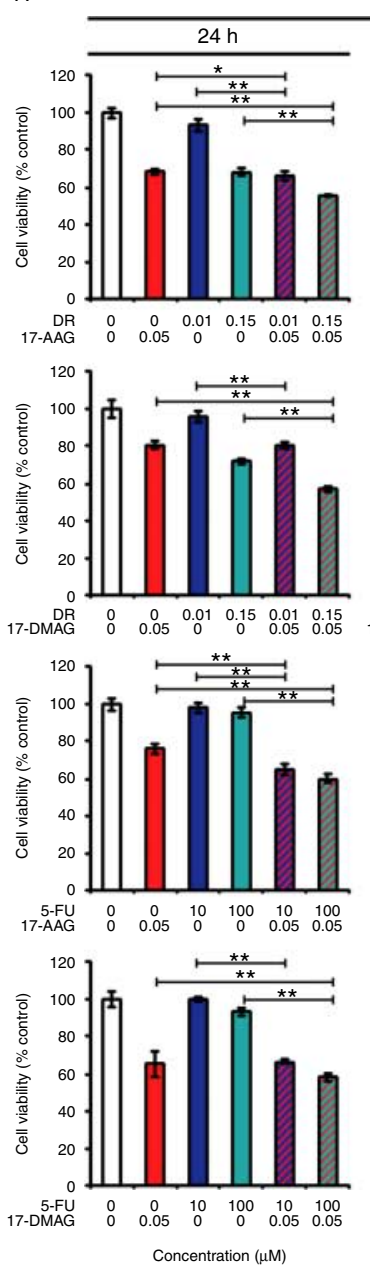

BON
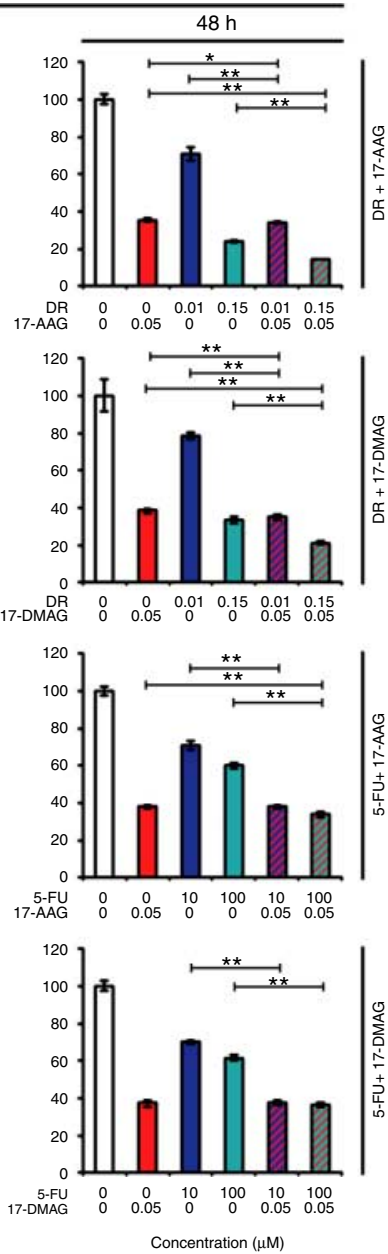

B
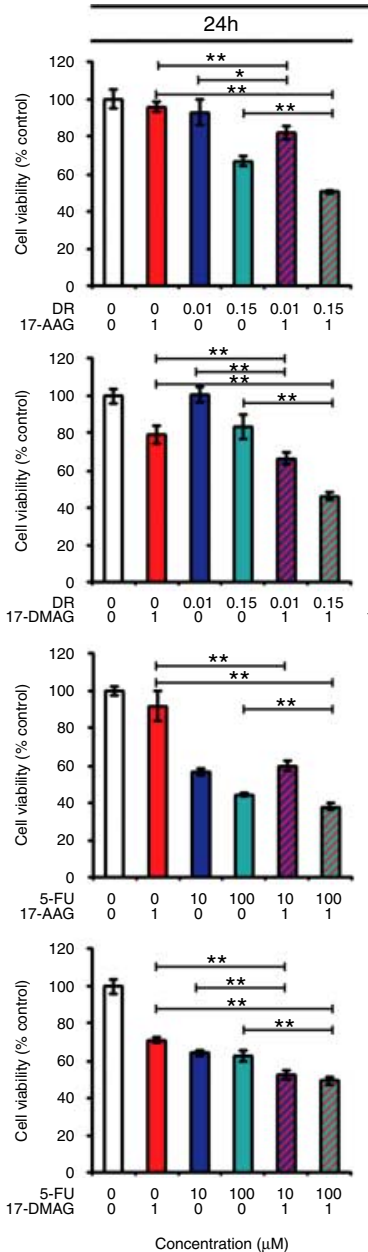

$\beta-$ TC-3
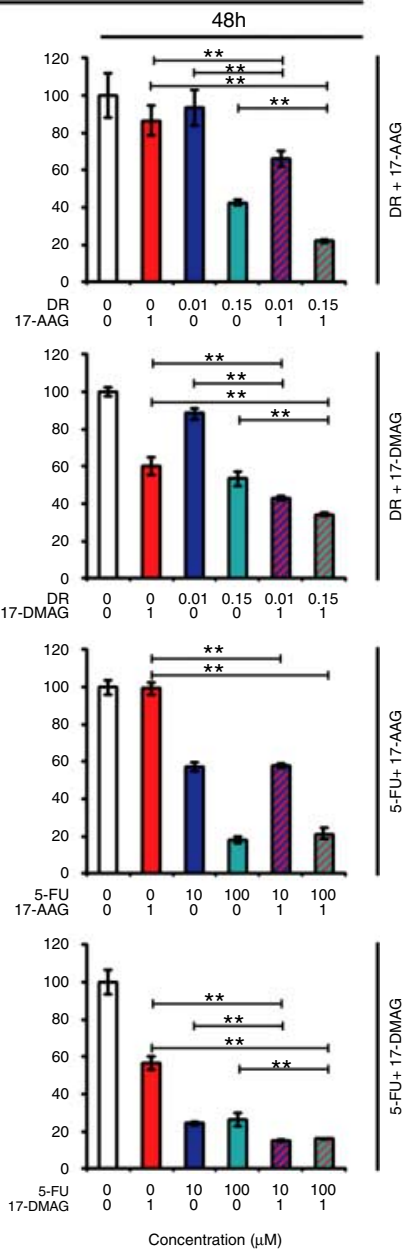

Figure 9 HSP90 inhibitors intensify the effect of established chemotherapeutic agents. (A) BON and (B) $\beta$-TC-3 cells were treated with HSP90 inhibitors, doxorubicin (DR), and/or 5-FU in the indicated concentrations, and cell viability was analyzed after 24 and $48 \mathrm{~h}$ with MTT assays. HSP90 inhibition intensified the effect of doxorubicin and 5-FU. ${ }^{\star} P<0.05 ;{ }^{\star \star} P<0.01$.

reduction of tumor size in only $10-15 \%$ of cases (Plockinger et al. 2004).

Underlining the applicability of HSP90 as a potential new therapeutic target in PET, we show that the HSP90 inhibitors 17-AAG and 17-DMAG reduce cell viability in a concentration- and time-dependent manner both in BON and $\beta$-TC-3, inducing a cell cycle arrest, mostly on the basis of a G1 and G2/M arrest. Moreover, inhibition of HSP90 markedly increases apoptosis in both the cell lines. Comparable in vitro results have been obtained in various other neoplasms, including urinary bladder cancer (Karkoulis et al. 2010), leukemia (Yu et al. 2005), endometrial cancer (Gossett et al. 2005), ovarian cancer (Gossett et al. 2005), and breast cancer (Gossett et al. 2005).

The fact that BON cells are more susceptible to inhibition of HSP90 than $\beta$-TC-3 cells could be due to a stronger dependence of BON cells on cell signaling pathways affected by inhibition of HSP90. Growth of BON cells was reported to be dependent on an autocrine feedback loop involving IGF1R leading to a constitutively activated PI3K/AKT signaling in BON cells (von Wichert et al. 2000). Underlining the importance of PI3K/AKT signaling in BON cells, inhibition of mammalian target of rapamycin (mTOR), which is a major downstream effector of AKT, potently induces growth inhibition in BON cells (Zitzmann et al. 2007, Missiaglia et al. 2010). In contrast, for $\beta$-TC-3, a specific dependence on signaling pathways affected by HSP90 inhibition has not been reported. Furthermore, 17-DMAG had a stronger effect on cell viability than 17-AAG in both BON and $\beta$-TC-3. In line with this, 17-DMAG was reported as a slightly more potent inhibitor of human HSP90 than 17-AAG 
with half maximal inhibitory concentrations (IC50) for 17-AAG and 17-DMAG being $119 \pm 23$ and $62 \pm$ $29 \mathrm{nM}$ respectively (Ge et al. 2006).

The relevance of HSP90 as a therapeutic target structure in PET could be superior to single target proteins of the PI3K/AKT and the Ras-Raf-MEK-Erk pathways because HSP90 interferes with both the pathways. In this way, HSP90 inhibitors suppress the activation of feedback loops that are responsible for the compensatory activation of two pathways after the inhibition of a single component of one pathway (Carracedo et al. 2008, Grant 2008). Furthermore, in molecular aspects, PET comprise a group of very heterogenous neoplasms with a variety of oncogenetic proteins contributing to their tumorigenesis (Zikusoka et al. 2005) so that interference with multiple oncogenetic proteins by HSP90 inhibitors could show favorable therapeutic effects. It was stated that this multitargeted approach with HSP90 inhibitors could also prevent the development of chemoresistance (Pearl et al. 2008). Activated oncoproteins seem to depend more on the function of HSP90 than on their nontransformed counterparts (Karapanagiotou et al. 2009). In cancer cells, HSP90 exists in an activated superchaperone complex, which is hypersensitive to HSP90 inhibition, while under normal conditions HSP90 is mainly uncomplexed (Kamal et al. 2003).

We examined the effects of a combined therapy with HSP90 inhibitors and established chemotherapeutic agents, doxorubicin or 5-FU (Plockinger et al. 2004). In other tumor entities, HSP90 inhibitors enhanced the effect of doxorubicin or 5-FU in vitro (Burkitt et al. 2007, Abramson et al. 2009, Kaiser et al. 2010). For PET, we could demonstrate similar effects. 17-AAG and 17-DMAG significantly enhanced the effect of doxorubicin and 5-FU on cell viability in vitro. Overexpression of the HSP90 isoforms HSP90 $\beta$ and TRAP1 has been reported to be associated with resistance to doxorubicin or 5-FU in colorectal cancer cells (Bertram et al. 1996, Costantino et al. 2009). The transcript levels of the latter were elevated in our freshly frozen PET samples. Thus, HSP90 inhibitors could improve the so far poor response characteristics of PET to systemic chemotherapy (Eriksson et al. 2009).

HSP90 inhibitors have been applied successfully in clinical studies. 17-DMAG, currently being in phase I clinical studies, showed antileukemia activity in three out of 17 patients with acute myeloid leukemia (Lancet et al. 2010). In another clinical study on patients with advanced malignancies including adenocarcinomas of the pancreas, the administration of 17-DMAG as single agent resulted in stable disease in nine out of 31 patients for a median of 4 months (Kummar et al. 2010). 17-AAG resulted in prolonged stable disease in two patients with melanoma (Workman 2004). In Her2-positive breast tumors, the combination of 17-AAG and trastuzumab induced regressions in $23 \%$ of the cases, including patients that had primarily not been responsive to trastuzumab therapy (Modi et al. 2007). Moreover, multiple myeloma patients responded to the combination of 17-AAG and bortezomib, even if they had been refractory to bortezomib as a single agent (Biamonte et al. 2010). However, in a phase II trial, the administration of 17-AAG in patients with metastatic melanoma reported no objective clinical responses, probably as a result of very low 17-AAG concentrations in the tumors (Solit et al. 2008). Another study with 17-AAG in patients with metastatic melanoma was stopped because endpoints were not reached, although some evidence of 17-AAG activity had been observed (Pacey et al. 2010).

Currently ongoing clinical trails of HSP90 inhibitors include, among others, three clinical trials of IPI-504, a water-soluble derivative of 17-AAG (Hanson \& Vesole 2009), in patients with advanced non-small cell lung cancer (NSCLC; http://clinicaltrials.gov). One trial examines the efficacy of IPI-504 in NSCLC patients with anaplastic lymphoma kinase (ALK) translocations after it has been shown in vitro that IPI-504 potently induces growth arrest and apoptosis in cells carrying ALK translocations (Normant et al. 2011). In another study, IPI-504 is administered together with the mTOR inhibitor everolimus in patients with KRAS mutant NSCLC (http://clinicaltrials.gov). Nevertheless, more recently, it has been suggested that mTOR inhibitors will be ineffective against cancer harboring KRAS mutations despite having PI3K/AKT/mTOR pathway activation (Mohseni \& Park 2010). Moreover, a phase II double-blind study compares the impact of IPI-504 in combination with docetaxel to placebo in combination with docetaxel on life expectancy in NSCLC patients. Before this, the combination of IPI-504 and docetaxel had demonstrated additive efficacy in murine xenograft models and a phase Ib trial was undertaken to identify the maximum tolerated dose of IPI-504 in combination with docetaxel, reporting no irreversible toxicities in 16 patients with advanced solid tumors, among these six with NSCLC (Riely et al. 2009). According to these findings and the promising in vitro results of our study, the effects of a HSP90 inhibition in PET should be further evaluated in animal models before clinical tests may be designed for PET.

In summary, in this study, we show that HSP90 is expressed in the vast majority of PET and safeguards 
many tumorigenic proteins. Inhibition of HSP90 results in a significant reduction of cell viability, cell cycle arrest, and increased apoptosis. The HSP90 inhibitors 17-AAG and 17-DMAG significantly increased the therapeutic effects of the doxorubicin and 5-FU in PET in vitro. Therefore, our findings suggest that HSP90 inhibition may be a valuable additive therapeutic strategy for advanced and progressed PET.

\section{Supplementary data}

This is linked to the online version of the paper at http://dx.doi.org/10.1530/ERC-11-0227.

\section{Declaration of interest}

The authors declare that there is no conflict of interest that could be perceived as prejudicing the impartiality of the research reported.

\section{Funding}

This research did not receive any specific grant from any funding agency in the public, commercial or not-for-profit sector.

\section{Acknowledgements}

The authors thank Eva Eiteneuer and Sarah Messnard for their excellent technical assistance.

\section{References}

Abramson JS, Chen W, Juszczynski P, Takahashi H, Neuberg D, Kutok JL, Takeyama K \& Shipp MA 2009 The heat shock protein 90 inhibitor IPI-504 induces apoptosis of AKT-dependent diffuse large B-cell lymphomas. British Journal of Haematology 144 358-366. (doi:10.1111/j.13652141.2008.07484.x)

Altieri DC 2010 Mitochondrial HSP90 chaperones as novel molecular targets in prostate cancer. Future Oncology 6 487-489. (doi:10.2217/fon.10.26)

Baselga J 2010 Treatment of HER2-overexpressing breast cancer. Annals of Oncology 21 (Suppl 7) vii36-vii40. (doi:10.1093/annonc/mdq421)

Bergmann F, Breinig M, Hopfner M, Rieker RJ, Fischer L, Kohler C, Esposito I, Kleeff J, Herpel E, Ehemann V et al. 2009 Expression pattern and functional relevance of epidermal growth factor receptor and cyclooxygenase-2: novel chemotherapeutic targets in pancreatic endocrine tumors? American Journal of Gastroenterology 104 171-181. (doi:10.1038/ajg.2008.33)

Bertram J, Palfner K, Hiddemann W \& Kneba M 1996 Increase of P-glycoprotein-mediated drug resistance by hsp 90 beta. Anticancer Drugs 7 838-845. (doi:10.1097/ 00001813-199611000-00004)
Biamonte MA, Van de Water R, Arndt JW, Scannevin RH, Perret D \& Lee WC 2010 Heat shock protein 90: inhibitors in clinical trials. Journal of Medicinal Chemistry 53 3-17. (doi:10.1021/jm9004708)

Breinig M, Caldas-Lopes E, Goeppert B, Malz M, Rieker R, Bergmann F, Schirmacher P, Mayer M, Chiosis G \& Kern MA 2009 Targeting heat shock protein 90 with non-quinone inhibitors: a novel chemotherapeutic approach in human hepatocellular carcinoma.

Hepatology 50 102-112. (doi:10.1002/hep.22912)

Burkitt M, Magee C, O’Connor D, Campbell F, Cornford P \& Greenhalf W 2007 Potentiation of chemotherapeutics by the HSP90 antagonist geldanamycin requires a steady serum condition. Molecular Carcinogenesis 46 466-475. (doi:10.1002/mc.20296)

Caldas-Lopes E, Cerchietti L, Ahn JH, Clement CC, Robles AI, Rodina A, Moulick K, Taldone T, Gozman A, Guo Y et al. 2009 HSP90 inhibitor PU-H71, a multimodal inhibitor of malignancy, induces complete responses in triple-negative breast cancer models. PNAS 106 8368-8373. (doi:10.1073/pnas. 0903392106)

Carracedo A, Ma L, Teruya-Feldstein J, Rojo F, Salmena L, Alimonti A, Egia A, Sasaki AT, Thomas G, Kozma SC et al. 2008 Inhibition of mTORC1 leads to MAPK pathway activation through a PI3K-dependent feedback loop in human cancer. Journal of Clinical Investigation 118 3065-3074.

Chen B, Piel WH, Gui L, Bruford E \& Monteiro A 2005 The HSP90 family of genes in the human genome: insights into their divergence and evolution. Genomics 86 627-637. (doi:10.1016/j.ygeno.2005.08.012)

Costantino E, Maddalena F, Calise S, Piscazzi A, Tirino V, Fersini A, Ambrosi A, Neri V, Esposito F \& Landriscina M 2009 TRAP1, a novel mitochondrial chaperone responsible for multi-drug resistance and protection from apoptotis in human colorectal carcinoma cells. Cancer Letters 279 39-46. (doi:10.1016/j.canlet.2009.01.018)

Csermely P, Schnaider T, Soti C, Prohaszka Z \& Nardai G 1998 The $90-\mathrm{kDa}$ molecular chaperone family: structure, function, and clinical applications. A comprehensive review. Pharmacology \& Therapeutics 79 129-168. (doi:10.1016/S0163-7258(98)00013-8)

Ehemann V, Hashemi B, Lange A \& Otto HF 1999 Flow cytometric DNA analysis and chromosomal aberrations in malignant glioblastomas. Cancer Letters 138 101-106. (doi:10.1016/S0304-3835(98)00383-8)

Ehemann V, Sykora J, Vera-Delgado J, Lange A \& Otto HF 2003 Flow cytometric detection of spontaneous apoptosis in human breast cancer using the TUNEL-technique. Cancer Letters 194 125-131. (doi:10.1016/S0304-3835 (03)00054-5)

Elmore LW, Forsythe R, Forsythe H, Bright AT, Nasim S, Endo K \& Holt SE 2008 Overexpression of telomeraseassociated chaperone proteins in prostatic intraepithelial neoplasia and carcinomas. Oncology Reports 20 613-617. (doi:10:3892/or_00000049) 
Eriksson B, Annibale B, Bajetta E, Mitry E, Pavel M, Platania M, Salazar R \& Plockinger U 2009 ENETS Consensus Guidelines for the Standards of Care in Neuroendocrine Tumors: chemotherapy in patients with neuroendocrine tumors. Neuroendocrinology 90 214-219. (doi:10.1159/000225950)

Fatrai S, Elghazi L, Balcazar N, Cras-Meneur C, Krits I, Kiyokawa H \& Bernal-Mizrachi E 2006 Akt induces beta-cell proliferation by regulating cyclin D1, cyclin D2, and p21 levels and cyclin-dependent kinase-4 activity. Diabetes 55 318-325. (doi:10.2337/diabetes.55.02.06. db05-0757)

Ge J, Normant E, Porter JR, Ali JA, Dembski MS, Gao Y, Georges AT, Grenier L, Pak RH, Patterson J et al. 2006 Design, synthesis, and biological evaluation of hydroquinone derivatives of 17-amino-17-demethoxygeldanamycin as potent, water-soluble inhibitors of HSP90. Journal of Medicinal Chemistry 49 4606-4615. (doi:10. 1021/jm0603116)

Gossett DR, Bradley MS, Jin X \& Lin J 2005 17-Allyamino17-demethoxygeldanamycin and 17-NN-dimethyl ethylene diamine-geldanamycin have cytotoxic activity against multiple gynecologic cancer cell types. Gynecologic Oncology 96 381-388. (doi:10.1016/j.ygyno.2004.10.009)

Grant S 2008 Cotargeting survival signaling pathways in cancer. Journal of Clinical Investigation 118 3003-3006. (doi:10.1172/JCI36898E1)

Grbovic OM, Basso AD, Sawai A, Ye Q, Friedlander P, Solit D \& Rosen N 2006 V600E B-Raf requires the HSP90 chaperone for stability and is degraded in response to HSP90 inhibitors. PNAS 103 57-62. (doi:10.1073/pnas. 0609973103)

Guo SS, Wu X, Shimoide AT, Wong J, Moatamed F \& Sawicki MP 2003 Frequent overexpression of cyclin D1 in sporadic pancreatic endocrine tumours. Journal of Endocrinology 179 73-79. (doi:10.1677/joe.0.1790073)

Hansel DE, Rahman A, House M, Ashfaq R, Berg K, Yeo CJ \& Maitra A 2004 Met proto-oncogene and insulinlike growth factor binding protein 3 overexpression correlates with metastatic ability in well-differentiated pancreatic endocrine neoplasms. Clinical Cancer Research 10 6152-6158. (doi:10.1158/1078-0432.CCR04-0285)

Hanson BE \& Vesole DH 2009 Retaspimycin hydrochloride (IPI-504): a novel heat shock protein inhibitor as an anticancer agent. Expert Opinion on Investigational Drugs 18 1375-1383. (doi:10.1517/13543780903158934)

Hay N 2005 The Akt-mTOR tango and its relevance to cancer. Cancer Cell 8 179-183. (doi:10.1016/j.ccr.2005. 08.008)

Heitz PU, Komminoth P, Perren A, Klimstra DS, Dayal Y, Bordi C, Lechago J, Centeno BA \& Klöppel G 2004 Pancreatic endocrine tumors: introduction. In Tumours of Endocrine Organs: Pathology and Genetics. World Health Organisation Classification of Tumors, Eds RA DeLellis, RV Lloyd, PU Heitz \& C Eng. Lyon: IARC Press.
Hennessy BT, Smith DL, Ram PT, Lu Y \& Mills GB 2005 Exploiting the PI3K/AKT pathway for cancer drug discovery. Nature Reviews. Drug Discovery 4 988-1004. (doi:10.1038/nrd1902)

Hollingshead M, Alley M, Burger AM, Borgel S, Pacula-Cox C, Fiebig HH \& Sausville EA 2005 In vivo antitumor efficacy of 17-DMAG (17-dimethylaminoethylamino17-demethoxygeldanamycin hydrochloride), a watersoluble geldanamycin derivative. Cancer Chemotherapy and Pharmacology 56 115-125. (doi:10.1007/s00280004-0939-2)

Kaiser M, Lamottke B, Mieth M, Jensen MR, Quadt C, Garcia-Echeverria C, Atadja P, Heider U, von Metzler I, Turkmen S et al. 2010 Synergistic action of the novel HSP90 inhibitor NVP-AUY922 with histone deacetylase inhibitors, melphalan, or doxorubicin in multiple myeloma. European Journal of Haematology 84 337-344. (doi:10.1111/j.1600-0609.2009.01403.x)

Kamal A, Thao L, Sensintaffar J, Zhang L, Boehm MF, Fritz LC \& Burrows FJ 2003 A high-affinity conformation of HSP90 confers tumour selectivity on HSP90 inhibitors. Nature 425 407-410. (doi:10.1038/nature01913)

Kang BH, Plescia J, Dohi T, Rosa J, Doxsey SJ \& Altieri DC 2007 Regulation of tumor cell mitochondrial homeostasis by an organelle-specific HSP90 chaperone network. Cell 131 257-270. (doi:10.1016/j.cell.2007.08.028)

Kang GH, Lee EJ, Jang KT, Kim KM, Park CK, Lee CS, Kang DY, Lee SH, Sohn TS \& Kim S 2010 Expression of HSP90 in gastrointestinal stromal tumours and mesenchymal tumours. Histopathology 56 694-701. (doi:10.1111/ j.1365-2559.2010.03550.x)

Karapanagiotou EM, Syrigos K \& Saif MW 2009 Heat shock protein inhibitors and vaccines as new agents in cancer treatment. Expert Opinion on Investigational Drugs 18 161-174. (doi:10.1517/13543780802715792)

Karkoulis PK, Stravopodis DJ, Margaritis LH \& Voutsinas GE 2010 17-Allylamino-17-demethoxygeldanamycin induces downregulation of critical HSP90 protein clients and results in cell cycle arrest and apoptosis of human urinary bladder cancer cells. BMC Cancer 10 481. (doi:10.1186/ 1471-2407-10-481)

Kazanjian KK, Reber HA \& Hines OJ 2006 Resection of pancreatic neuroendocrine tumors: results of 70 cases. Archives of Surgery 141 765-769 (discussion 769-770). (doi:10.1001/archsurg.141.8.765)

Kirshbom PM, Kherani AR, Onaitis MW, Hata A, Kehoe TE, Feldman C, Feldman JM \& Tyler DS 1999 Foregut carcinoids: a clinical and biochemical analysis. Surgery 126 1105-1110. (doi:10.1067/msy.2099.101430)

Kummar S, Gutierrez ME, Gardner ER, Chen X, Figg WD, Zajac-Kaye M, Chen M, Steinberg SM, Muir CA, Yancey MA et al. 2010 Phase I trial of 17-dimethylaminoethylamino-17-demethoxygeldanamycin (17-DMAG), a heat shock protein inhibitor, administered twice weekly in patients with advanced malignancies. European Journal of Cancer 46 340-347. (doi:10.1016/j.ejca.2009.10.026) 
Lancet JE, Gojo I, Burton M, Quinn M, Tighe SM, Kersey K, Zhong Z, Albitar MX, Bhalla K, Hannah AL et al. 2010 Phase I study of the heat shock protein 90 inhibitor alvespimycin (KOS-1022, 17-DMAG) administered intravenously twice weekly to patients with acute myeloid leukemia. Leukemia 24 699-705. (doi:10.1038/ leu.2009.292)

Lee W, Patel JH \& Lockhart AC 2009 Novel targets in esophageal and gastric cancer: beyond antiangiogenesis. Expert Opinion on Investigational Drugs 18 1351-1364. (doi:10.1517/13543780903179286)

Mebratu Y \& Tesfaigzi Y 2009 How ERK1/2 activation controls cell proliferation and cell death: is subcellular localization the answer? Cell Cycle 8 1168-1175. (doi:10. 4161/cc.8.8.8147)

Milicevic Z, Bogojevic D, Mihailovic M, Petrovic M \& Krivokapic Z 2008 Molecular characterization of hsp90 isoforms in colorectal cancer cells and its association with tumour progression. International Journal of Oncology 32 1169-1178.

Missiaglia E, Dalai I, Barbi S, Beghelli S, Falconi M, della Peruta M, Piemonti L, Capurso G, Di Florio A, delle Fave $\mathrm{G}$ et al. 2010 Pancreatic endocrine tumors: expression profiling evidences a role for AKT-mTOR pathway. Journal of Clinical Oncology 28 245-255. (doi:10.1200/ JCO.2008.21.5988)

Modi S, Stopeck AT, Gordon MS, Mendelson D, Solit DB, Bagatell R, Ma W, Wheler J, Rosen N, Norton L et al. 2007 Combination of trastuzumab and tanespimycin (17-AAG, KOS-953) is safe and active in trastuzumabrefractory HER-2 overexpressing breast cancer: a phase I dose-escalation study. Journal of Clinical Oncology 25 5410-5417. (doi:10.1200/JCO.2007.11.7960)

Mohseni M \& Park BH 2010 PIK3CA and KRAS mutations predict for response to everolimus therapy: now that's RAD001. Journal of Clinical Investigation 120 2655-2658. (doi:10.1172/JCI44026)

Ni M \& Lee AS 2007 ER chaperones in mammalian development and human diseases. FEBS Letters 581 3641-3651. (doi:10.1016/j.febslet.2007.04.045)

Normant E, Paez G, West KA, Lim AR, Slocum KL, Tunkey C, McDougall J, Wylie AA, Robison K, Caliri K et al. 2011 The HSP90 inhibitor IPI-504 rapidly lowers EML4ALK levels and induces tumor regression in ALK-driven NSCLC models. Oncogene 30 2581-2586. (doi:10.1038/ onc.2010.625)

Ogata M, Naito Z, Tanaka S, Moriyama Y \& Asano G 2000 Overexpression and localization of heat shock proteins mRNA in pancreatic carcinoma. Journal of Nippon Medical School 67 177-185. (doi:10.1272/jnms.67.177)

Pacey S, Gore M, Chao D, Banerji U, Larkin J, Sarker S, Owen K, Asad Y, Raynaud F, Walton M et al. 2010 A phase II trial of 17-allylamino, 17-demethoxygeldanamycin (17-AAG, tanespimycin) in patients with metastatic melanoma. Investigational New Drugs 30 341-349. (doi:10.1007/510637-010-9493-4)
Pan Z, Erkan M, Streit S, Friess H \& Kleeff J 2009 Silencing of GRP94 expression promotes apoptosis in pancreatic cancer cells. International Journal of Oncology 35 823-828. (doi:10.3892/ijo_00000395)

Pearl LH, Prodromou C \& Workman P 2008 The HSP90 molecular chaperone: an open and shut case for treatment. Biochemical Journal 410 439-453. (doi:10.1042/ BJ20071640)

Peng B, Xu L, Cao F, Wei T, Yang C, Uzan G \& Zhang D 2010 HSP90 inhibitor, celastrol, arrests human monocytic leukemia cell U937 at G0/G1 in thiol-containing agents reversible way. Molecular Cancer 9 79. (doi:10.1186/ 1476-4598-9-79)

Pick E, Kluger Y, Giltnane JM, Moeder C, Camp RL, Rimm DL \& Kluger HM 2007 High HSP90 expression is associated with decreased survival in breast cancer. Cancer Research 67 2932-2937. (doi:10.1158/00085472.CAN-06-4511)

Plockinger U, Rindi G, Arnold R, Eriksson B, Krenning EP, de Herder WW, Goede A, Caplin M, Oberg K, Reubi JC et al. 2004 Guidelines for the diagnosis and treatment of neuroendocrine gastrointestinal tumours. A consensus statement on behalf of the European Neuroendocrine Tumour Society (ENETS). Neuroendocrinology $\mathbf{8 0}$ 394-424. (doi:10.1159/000085237)

Porter JR, Fritz CC \& Depew KM 2010 Discovery and development of HSP90 inhibitors: a promising pathway for cancer therapy. Current Opinion in Chemical Biology 14 412-420. (doi:10.1016/j.cbpa.2010.03.019)

Rexen P \& Emborg C 1992 Investigation of different modifications to the tetrazolium based colorimetric viability assay. Biotechnology Techniques 6 255-260. (doi:10.1007/BF02439354)

Richardson PG, Badros AZ, Jagannath S, Tarantolo S, Wolf JL, Albitar M, Berman D, Messina M \& Anderson KC 2010 Tanespimycin with bortezomib: activity in relapse$\mathrm{d} /$ refractory patients with multiple myeloma. British Journal of Haematology 150 428-437. (doi:10.1111/j. 1365-2141.2010.08264.x)

Riely GJ, Stoller R, Egorin M, Solit D, Dunbar J, Savage A, Walker J, Grayzel D, Ross R \& Weiss GJ 2009 A phase Ib trial of IPI-504 (retaspimycin hydrochloride), a novel HSP90 inhibitor, in combination with docetaxel. Journal of Clinical Oncology 27 S3547. (doi:10.1200/ JCO.2008.17.4656)

Shimamura T \& Shapiro GI 2008 Heat shock protein 90 inhibition in lung cancer. Journal of Thoracic Oncology 3 S152-S159. (doi:10.1097/JTO.0b013e318174ea3a)

Sippel RS, Carpenter JE, Kunnimalaiyaan M, Lagerholm S \& Chen H 2003 Raf-1 activation suppresses neuroendocrine marker and hormone levels in human gastrointestinal carcinoid cells. American Journal of Physiology. Gastrointestinal and Liver Physiology 285 G245-G254. (doi:10.1152/ajpgi.00420.2002)

Solit DB, Osman I, Polsky D, Panageas KS, Daud A, Goydos JS, Teitcher J, Wolchok JD, Germino FJ, Krown SE et al. 2008 Phase II trial of 17-allylamino- 
17-demethoxygeldanamycin in patients with metastatic melanoma. Clinical Cancer Research 14 8302-8307. (doi:10.1158/1078-0432.CCR-08-1002)

Song D, Chaerkady R, Tan AC, Garcia-Garcia E, Nalli A, Suarez-Gauthier A, Lopez-Rios F, Zhang XF, Solomon A, Tong J et al. 2008 Antitumor activity and molecular effects of the novel heat shock protein 90 inhibitor, IPI-504, in pancreatic cancer. Molecular Cancer Therapeutics 7 3275-3284. (doi:10.1158/1535-7163. MCT-08-0508)

Sreedhar AS, Kalmar E, Csermely P \& Shen YF 2004 HSP90 isoforms: functions, expression and clinical importance. FEBS Letters 562 11-15. (doi:10.1016/S0014-5793(04) 00229-7)

Suzuki Y, Kondo Y, Hara S, Kimata R \& Nishimura T 2010 Effect of the hsp90 inhibitor geldanamycin on androgen response of prostate cancer under hypoxic conditions. International Journal of Urology 17 281-285. (doi:10. 1111/j.1442-2042.2010.02450.x)

Tannapfel A, Vomschloss S, Karhoff D, Markwarth A, Hengge UR, Wittekind C, Arnold R \& Horsch D 2005 BRAF gene mutations are rare events in gastroenteropancreatic neuroendocrine tumors. American Journal of Clinical Pathology 123 256-260. (doi:10. 1309/YQBR9C05RU4DD3RN)

Trepel J, Mollapour M, Giaccone G \& Neckers L 2010 Targeting the dynamic HSP90 complex in cancer. Nature Reviews. Cancer 10 537-549. (doi:10.1038/nrc2887)

Usmani SZ, Bona R \& Li Z 200917 AAG for HSP90 inhibition in cancer - from bench to bedside. Current Molecular Medicine 9 654-664. (doi:10.2174/ 156652409788488757)

von Wichert G, Jehle PM, Hoeflich A, Koschnick S, Dralle H, Wolf E, Wiedenmann B, Boehm BO, Adler G \& Seufferlein T 2000 Insulin-like growth factor-I is an autocrine regulator of chromogranin A secretion and growth in human neuroendocrine tumor cells. Cancer Research 60 4573-4581.
Workman P 2004 Combinatorial attack on multistep oncogenesis by inhibiting the HSP90 molecular chaperone. Cancer Letters 206 149-157. (doi:10.1016/j.canlet. 2003.08.032)

Workman P, Burrows F, Neckers L \& Rosen N 2007 Drugging the cancer chaperone HSP90: combinatorial therapeutic exploitation of oncogene addiction and tumor stress. Annals of the New York Academy of Sciences 1113 202-216. (doi:10.1196/annals.1391.012)

Wu X, Wanders A, Wardega P, Tinge B, Gedda L, Bergstrom S, Sooman L, Gullbo J, Bergqvist M, Hesselius P et al. 2009 HSP90 is expressed and represents a therapeutic target in human oesophageal cancer using the inhibitor 17-allylamino-17-demethoxygeldanamycin. British Journal of Cancer 100 334-343. (doi:10.1038/sj.bjc.6604855)

Yu WJ, Rao Q, Wang M, Tian Z, Liu XR, Lin D \& Wang JX 2005 The heat shock protein 90 inhibitor induces apoptosis and differentiation of Kasumi-1 and its mechanisms. Zhonghua Xue Ye Xиe Za Zhi 26 728-731.

Zhang WL, Gao XQ, Han JX, Wang GQ \& Yue LT 2009 Expressions of heat shock protein (HSP) family HSP 60, 70 and 90alpha in colorectal cancer tissues and their correlations to pathohistological characteristics. Ai Zheng 28 612-618.

Zikusoka MN, Kidd M, Eick G, Latich I \& Modlin IM 2005 The molecular genetics of gastroenteropancreatic neuroendocrine tumors. Cancer 104 2292-2309. (doi:10.1002/ cncr.21451)

Zitzmann K, De Toni EN, Brand S, Goke B, Meinecke J, Spottl G, Meyer HH \& Auernhammer CJ 2007 The novel mTOR inhibitor RAD001 (everolimus) induces antiproliferative effects in human pancreatic neuroendocrine tumor cells. Neuroendocrinology 85 54-60. (doi:10.1159/ 000100057)

Received in final form 17 November 2011 Accepted 22 December 2011 Made available online as an Accepted Preprint 22 December 2011 